\title{
Falciparum Malaria Cured by Quinine Followed by Sulfadoxine-Pyrimethamine
}

\author{
A. P. HALL, E. B. DOBERSTYN, V. METTAPRAKONG, P. SONKOM
}

British Medical fournal, 1975, 2, 15-17

\section{Summary}

Quinine (at least four doses given at intervals of eight to 12 hours) followed by a single dose of sulfadoxinepyrimethamine (Fansidar) is the most effective treatment of chloroquine-resistant falciparum malaria. This regimen cured $96 \%$ of patients (302 out of 314 ) with an average initial parasite count of $90 \times 10^{\circ} / 1$.

\section{Introduction}

The treatment of chloroquine-resistant falciparum malaria has hitherto been confusing. No clear-cut regimen has yet emerged (Lancet, 1971). The World Health Organization (1973) mentioned 16 different regimens involving 12 drugs administered over one to 14 days. Based on the results of this study we recommend one regimen with three drugs given in about three days.

In south-east Thailand a six-day course of quinine cured $85 \%$ of patients with falciparum malaria (Hall et al., 1975 a); a single dose of sulfadoxine-pyrimethamine (Fansidar) was also $85 \%$ curative (Doberstyn et al., 1975). Therefore, we tested a short course of quinine (average three days) followed by Fansidar in about 400 patients.

\section{Methods}

The Trad Provincial Hospital is in south-east Thailand 250 miles $(400 \mathrm{~km})$ from Bangkok. Malaria is endemic in the area throughout the year. Volunteers were selected for the study if their asexual parasite count of Plasmodium falciparum was at least $1 \times 10^{9} / 1$. Initially only men were studied. When quinine-Fansidar was shown to be the most effective treatment it was used routinely in adults and children. Patients with coincident vivax malaria were treated but not included in this study.

Quantitative parasite counts (Earle and Perez, 1932) were performed at least twice daily in hospital on finger-prick specimens taken at 07.00 and 14.00 hours and at follow-up examinations on days 14, 21, and 28. Many patients returned for further blood tests after day 28. The packed cell volume and leucocyte count were determined on admission and whenever clinically indicated.

The drugs were administered by the study physicians during ward rounds, usually at $06.00,14.00$, and 22.00 hours. Intravenous quinine was administered as the dihydrochloride salt. The standard dose in adults was $490 \mathrm{mg}$ base in $500 \mathrm{ml}$ normal saline infused over four hours. Oral quinine was prescribed as tablets of quinine sulphate each containing $270 \mathrm{mg}$ of base. The routine formulation was a sugarcoated tablet, but plain tablets were occasionally used, especially in small children. The standard dose in adults was $540 \mathrm{mg}$ (two tablets) every eight hours. Each plain tablet of Fansidar contained $25 \mathrm{mg}$ pyrimethamine and $500 \mathrm{mg}$ sulfadoxine. The standard dose in adults

U.S. Army Medical Component, S.E.A.T.O., Bangkok, Thailand A. P. HALL M.B., F.A.C.P., Colonel, M.c., Chief of Department of Medicine

E. B. DOBERSTYN, M.D., D.T.M.\&H., Assistant Chief
V. METTAPRAKONG, Medical Technician

Trad Provincial Hospital, Thailand

P. SONKOM, M.D., Medical Director was three tablets given with or eight hours after the last dose of quinine.

Quinine concentrations in random serum samples were determined by the benzene extraction method of Brodie et al. (1947), an accurate technique (Hall et al., 1973).

Parasite and fever clearance times were determined in hours. The patients' temperature charts were retained for analysis. Patients were considered radically cured ( $S$. response) when their parasitaemia was cleared by treatment and had not reappeared before day 29 (the day of admission being called day 0). The W.H.O. (1967) classification was used (see table II).

\section{Results}

Altogether 414 patients were admitted to the study. Many were seriously ill on admission and $13(3 \%)$ died before receiving Fansidar. Nine patients discharged themselves from hospital after clinical improvement but before receiving Fansidar. Thus 392 patients received quinine-Fansidar therapy. The average age of the group was 23.9 (range 1-73) years and the average weight $45 \cdot 4$ (range 5-80) $\mathrm{kg}$. Only seven patients were female since we usually confined our studies to male patients.

\section{INITIAL MANAGEMENT}

Most patients were fairly seriously ill on admission. The average parasite count $\left(90.676 \times 10^{\circ} / 1\right)$ was much higher than in our other therapeutic studies (for example, Hall et al., $1975 a$ ), and the average parasite clearance time of $77 \cdot 3$ hours indicated a satisfactory response (table I). Clearance of parasitaemia was slow in a few patients, especially those with high counts-for example, over $200 \times 10^{\circ} / 1$-and was possibly due to partial resistance to quinine. A typical patient, with parasite count of $252.72 \times 10^{\%} / 1$, received 18 doses (six days) of quinine before the Fansidar. His parasite clearance time was prolonged at 147 hours. Despite the slow clinical response

TABLE I-Results of Treatment with up to 18 Doses of Quinine Followed by Single Dose of Fansidar in 314 Cases of Malaria and with Fansidar Alone in 39 Cases*.

\begin{tabular}{|c|c|c|c|c|c|c|c|}
\hline $\begin{array}{l}\text { No. of } \\
\text { Doses of } \\
\text { Quinine }\end{array}$ & $\begin{array}{c}\text { Average } \\
\text { Parasite } \\
\text { Count for } \\
\text { Group } \\
(\times 10 \% 1)\end{array}$ & $\begin{array}{l}\text { Average } \\
\text { Parasite } \\
\text { Clearance } \\
\text { Time (h) }\end{array}$ & $\begin{array}{c}\text { Average } \\
\text { Initial } \\
\text { Fever } \\
\left({ }^{\circ} \mathrm{C}\right) \\
\end{array}$ & $\begin{array}{c}\text { Average } \\
\text { Fever } \\
\text { Clearance } \\
\text { Time (h) }\end{array}$ & \begin{tabular}{|c|} 
No. of \\
Treatment \\
Failures \\
(RI-III) \\
\end{tabular} & $\begin{array}{c}\text { No. } \\
\text { Cured } \\
(S)\end{array}$ & $\begin{array}{l}\text { Cure } \\
\text { Rate }\end{array}$ \\
\hline $0^{*}$ & $60 \cdot 230$ & 73.0 & 39.5 & 62.6 & 6 & 33 & $85 \%$ \\
\hline $\begin{array}{l}1 \\
2 \\
3 \\
4 \dagger \\
5 \\
6 \\
7 \\
8 \\
9 \\
10 \\
11 \\
12 \\
13 \\
14 \\
15\end{array}$ & $\begin{array}{r}57 \cdot 742 \\
65.510 \\
71.719 \\
124.624 \\
76.385 \\
81.481 \\
114.285 \\
99.600 \\
64.067 \\
98 \cdot 651 \\
66.949 \\
285.057 \\
242.345 \\
269.754 \\
138.340\end{array}$ & $\begin{array}{r}67.3 \\
71.6 \\
67.7 \\
72.4 \\
67.4 \\
73.8 \\
75.3 \\
78.2 \\
76.6 \\
81.5 \\
91.8 \\
88.0 \\
92.5 \\
108.8 \\
117.0\end{array}$ & $\begin{array}{l}39 \cdot 1 \\
39 \cdot 5 \\
39 \cdot 3 \\
39 \cdot 4 \\
39 \cdot 5 \\
38 \cdot 8 \\
39 \cdot 4 \\
39 \cdot 3 \\
39 \cdot 2 \\
38 \cdot 5 \\
39 \cdot 6 \\
39.0 \\
39 \cdot 2 \\
38 \cdot 7 \\
40.3\end{array}$ & $\begin{array}{r}50.7 \\
57.5 \\
55.6 \\
43.4 \\
54.5 \\
62.5 \\
58.0 \\
70.3 \\
59.5 \\
69.5 \\
102.0 \\
74.8 \\
93.5 \\
91.0 \\
109.5\end{array}$ & $\begin{array}{l}0 \\
2 \\
0 \\
0 \\
2 \\
1 \\
0 \\
1 \\
5 \\
0 \\
0 \\
1 \\
0 \\
0 \\
0\end{array}$ & $\begin{array}{r}21 \\
22 \\
24 \\
22 \\
22 \\
21 \\
23 \\
21 \\
83 \\
20 \\
7 \\
6 \\
3 \\
3 \\
2\end{array}$ & \\
\hline $\begin{array}{l}10 \\
17 \\
18\end{array}$ & $\begin{array}{l}515 \cdot 060 \\
252 \cdot 720\end{array}$ & $\begin{array}{l}130.0 \\
147.0\end{array}$ & $\begin{array}{l}40 \cdot 1 \\
40 \cdot 2\end{array}$ & $\begin{array}{r}82 \cdot 0 \\
137 \cdot 0\end{array}$ & $\begin{array}{l}0 \\
0\end{array}$ & $\begin{array}{l}1 \\
1\end{array}$ & \\
\hline Total & 90.676 & $77 \cdot 3$ & $39 \cdot 2$ & 61.5 & 12 & 302 & $96 \%$ \\
\hline
\end{tabular}

* Study reported in detail elsewhere (Doberstyn et al., 1975).

$\dagger$ For optimum clinical response at least four doses of quinine should be given before the Fansidar. 
his blood was free of parasites on days 14,21 , and 28 , so that he was regarded as radically cured.

The average fever clearance time was 61.5 hours. In a few patients a persistent fever was probably caused by the quinine. Since the average course of quinine was short quinine fever was not so frequent a problem as with longer courses in previous studies (Hall, 1974). In some patients receiving only a few doses of quinine a rising fever on day 1 or day 2 was probably caused by the Fansidar, since the fever patterns were similar to those found in patients receiving Fansidar alone (Doberstyn et al., 1975). Many patients were discharged when they felt better but before the fever and parasitaemia had cleared.

Of the 392 patients $322(82 \%)$ received at least one dose (average 1.5 doses, range 1-7) of quinine as a continuous intravenous infusion. The standard dose of quinine base was $10 \mathrm{mg} / \mathrm{kg}$ but in small children a lower dose was often used to prevent toxicity. The adult intravenous dose $(490 \mathrm{mg}$ quinine base in the dihydrochloride salt) was usually given in $500 \mathrm{ml}$ normal saline. The optimum infusion time for a rapid response without toxicity was four hours. Half-strength solutions $(0.5 \mathrm{mg}$ quinine base $/ \mathrm{ml})$ were administered, especially in children, when quinine toxicity was suspected. In comatose adults the optimum dose was not more than $1000 \mathrm{mg}$ quinine base (two doses)/ 24 hours given in 1000-1500 ml fluid intravenously. Quinine metabolism is impaired in severe falciparum malaria and the half life of the drug is prolonged. Thus lower or less frequent doses are needed to prevent overdosage. In several of our patients toxic levels of serum quinine (concentrations over $30.8 \mu \mathrm{mol} / 1(10 \mathrm{mg} / \mathrm{l})$ ) occurred despite subnormal doses of the drug. Nevertheless, quinine is the only drug that brings severe falciparum infections under satisfactory control in south-east Thailand.

\section{RADICAL CURE}

Follow-up examinations were completed in 314 patients, of whom $302(96 \%)$ were radically cured (table II). The quinineFansidar regimen was more effective than a six-day course of quinine, or Fansidar alone, in our test system.

TABLE II-Cure Rates of Falciparum Malaria in Thailand During 1973-4 with Four Different Regimens

\begin{tabular}{|c|c|c|c|c|c|c|c|c|}
\hline & & \multirow{2}{*}{$\begin{array}{c}\text { Average } \\
\text { Duration } \\
\text { of Therapy }\end{array}$} & \multirow{2}{*}{$\begin{array}{c}\text { Average } \\
\text { Parasitaemia } \\
\left(\times 10^{9} / 1\right)\end{array}$} & \multicolumn{4}{|c|}{ Therapeutic Result* } & \multirow{2}{*}{$\begin{array}{l}\text { Cure } \\
\text { Rate } \\
\left({ }^{0}{ }_{0}\right)\end{array}$} \\
\hline & & & & $\overline{\text { RIII }}$ & $\overline{R I I}$ & RI & $\mathrm{s}$ & \\
\hline $\begin{array}{ll}\text { Quinine + Fansidar } \\
\text { Quinine } \\
\text { Fansidar } \\
\text { Chloroquine } & \ldots \\
\end{array}$ & $\begin{array}{l}\ldots \\
\cdots \\
\cdots\end{array}$ & $\begin{array}{l}3 \text { Days } \\
6 \text { Days } \\
1 \text { Dose } \\
3 \text { Days }\end{array}$ & $\begin{array}{l}90 \\
28 \\
56 \\
15\end{array}$ & $\begin{array}{l}1 \\
4 \\
2\end{array}$ & 8 & $\begin{array}{r}12 \\
9 \\
2 \\
1\end{array}$ & $\begin{array}{r}302 \\
55 \\
33\end{array}$ & $\begin{array}{r}96 \\
85 \\
85 \\
0\end{array}$ \\
\hline
\end{tabular}

${ }^{*} \mathrm{RIII}=$ No marked reduction of asexual parasitaemia. $\mathrm{RII}=$ Marked reduction of asexual parasitaemia but no clearance. $\mathrm{RI}=$ Clearance of asexual parasitaemia followed by recrudescence. $\mathbf{S}=$ Clearance of asexual parasitaemia without recrudes-

† Study reported in detail by Hall et al. (1975 a).

†Dose in adults $1.5 \mathrm{~g}$ sulfadoxine and $75 \mathrm{mg}$ pyrimethamine.

Initially all patients received nine doses of quinine. The questions arose whether a shorter course of quinine would be equally effective and whether, in severe cases, a longer course of quinine would be more effective. Thus further patients received one to 18 doses of quinine before the single dose of Fansidar. To our surprise the cure rate was about $96 \%$ throughout the range (table I). The cure rate of $98 \%$ (43 out of 44 patients) with 10 to 18 doses, however, was impressive since the patients were mostly seriously ill and their average parasite count was high $\left(166 \times 10^{9} / 1\right)$.

When the course of quinine was short (under four doses) the initial clinical improvement was not always maintained and a temporary resurgence of fever and other symptoms often occurred on about the second day. If at least four doses of quinine were given optimal clinical improvement usually resulted. The shortest fever clearance time occurred with the four-dose course (table I). Longer courses of quinine appeared to be indicated in patients with high initial parasite counts or evidence of chronic disease-for example, large spleens.

\section{TOXICITY}

Quinine caused typical mild side effects in most patients-for example, nausea and tinnitus. When blurred vision or other serious symptoms occurred the dose was reduced. Serious side effects such as coma or convulsions were more common in children than in adults. Reduction or stopping of dosage usually resulted in a rapid decrease in toxicity.

Serious toxicity attributable to the Fansidar did not occur in any of the 392 patients who received the quinine-Fansidar regimen. Fansidar alone, however, often causes fever and less often urticarial rashes (Doberstyn et al., 1975).

\section{$\cos \mathrm{T}$}

The cost of treatment comprises the hospital costs (if the patient requires admission) plus the cost of the drugs. The 392 patients were in hospital for an average of only 3.8 days, which was brief in relation to the average clinical severity of the group and reflects the fact that quinine usually acts rapidly.

We found that the minimum effective regimen was four doses of quinine plus Fansidar. At the time of the study quinine cost the hospital pharmacy about $\$$ U.S.0.04 per tablet and Fansidar about $\$ 0.15$ per tablet. Thus the cost of the oral regimen was at least $\$ 0 \cdot 77$. This was less than any other effective regimen. Intravenous therapy was much more expensive because intravenous fluid was relatively costly.

Other relevant factors are the duration of treatment, the total number of doses, and their frequency. Optimum quinineFansidar therapy comprises at least five doses (four of quinine, one of Fansidar) given over two days at eight to 12hour intervals. These parameters are less than for any other effective regimen.

\section{Discussion}

This study has established that quinine followed by Fansidar is the treatment of choice for chloroquine-resistant falciparum malaria. The regimen is theoretically sound because it comprises the rapidly acting drug quinine followed by the long-acting combination of sulfadoxine and pyrimethamine (Fansidar). The quinine brings the infection under control and the Fansidar aids its eradication. This regimen is useful because, as we found, Fansidar is non-toxic when given at the end of a course of quinine; it is practical because it is completed in about three days, thus allowing the patient to be discharged promptly.

The value of an antimalarial regimen may be determined by five criteria-namely, efficacy, toxicity, cost, duration of therapy, and length of hospital stay. These criteria must be judged in relation to the average severity of the cases being treated, which is indicated by the clinical condition and the average parasite count. In view of all these factors the quinineFansidar regimen is the best that we have tested.

The components of the quinine-Fansidar regimen are more powerful antimalarials than any other drugs. For chloroquineresistant falciparum malaria quinine is the only rapidly acting drug currently available. The components of Fansidar act longer than any other similar drugs (table III). Fansidar is more effective in the radical cure of falciparum malaria than pyrimethamine with dapsone (Segal et al., 1975) or pyrimethamine with diformyldapsone (Doberstyn et al., 1975). 
TABLE III-Half Lives of Drugs Used for Malaria

\begin{tabular}{|c|c|c|c|c|}
\hline & & & Half Life (h) & Reference \\
\hline $\begin{array}{l}\text { Sulfadoxine ... } \\
\text { Pyrimethamine } \\
\text { Sulfametopyrazine } \\
\text { Diformyldapsone } \\
\text { Dapsone } \\
\text { Sulphadiazine . } \\
\text { Sulphamethoxazole* } \\
\text { Trimethoprim* }\end{array}$ & $\begin{array}{l}\ldots \\
\cdots \\
\cdots \\
\cdots \\
\cdots\end{array}$ & $\begin{array}{l}\ldots \\
\because \\
\cdots \\
\cdots \\
\cdots \\
\cdots\end{array}$ & $\begin{array}{r}200 \\
96 \\
65 \\
30 \\
21 \\
17 \\
9 \\
9\end{array}$ & $\begin{array}{l}\text { Brooks et al. (1969) } \\
\text { Smith and Ihrig (1959) } \\
\text { Seneca (1966) } \\
\text { Sonntag et al. (1972) } \\
\text { Glazko et al. (1968) } \\
\text { Richards (1970) } \\
\text { Schwartz and Rieder (1970) } \\
\text { Schwartz and Rieder (1970) }\end{array}$ \\
\hline
\end{tabular}

-Sulphamethoxazole and trimethoprim are the constituents of co-trimoxazole.

Single-dose Fansidar is more effective than multi-dose clindamycin or tetracycline (Hall et al., 1975 b). Fansidar alone often produces toxic manifestations such as fever and urticaria and is slow acting, but when given at the end of a course of quinine it caused no serious toxicity in over 300 patients. Sequential quinine-Fansidar is also more logical than combination therapy because antimalarial activity in the blood is thereby maintained longer.

Quinine has, of course, been used for malaria for severalhundred years. Sulfadoxine was introduced for malaria by Laing (1964). Chin et al. (1966) discovered the antimalarial potentiation of pyrimethamine by sulfadoxine. The U.S. Army found that a 14-day course of quinine with an initial dose of sulfadoxine and pyrimethamine was effective against falciparum malaria (Bartelloni et al., 1967; Brooks et al., 1969). Nevertheless, the official U.S. Army regimen is still quinine for 10 days, pyrimethamine for three days, and dapsone for 28 days (Neva et al., 1970). In Laos a 7-10-day course of quinine plus an initial dose of Fansidar was found to be effective (Ebisawa et al., 1970). Quinine with Fansidar, however, is not mentioned in the regimens recommended by the W.H.O. (1973) or in the latest edition of a leading textbook of medicine (Harrison, 1974).

We recommend that quinine (at least four doses) followed by Fansidar should be officially adopted as the standard regimen for chloroquine-resistant falciparum malaria. It should be the yardstick by which newer drugs are compared.

Quinine is more effective than chloroquine against chloroquine-sensitive falciparum malaria from Africa (Ansdell $e t$ al., 1974). Therefore, comparative studies of quinine and chloroquine with and without terminal Fansidar for African falciparum malaria are indicated.
We have found that clear-cut results are readily obtained without risk to the patients when moderate and severe rather than mild cases are selected for precise evaluation of effective regimens. Mildly ill patients, presumably semi-immune, are often cured by minimal therapy; such results can confuse comparative studies.

We thank Rear Admiral Samrit Jatinandana, Royal Thai Navy, and Colonels Phillip E. Winter and Craig J. Canfield, U.S. Army, for their help and encouragement during this study.

This paper forms contribution No. 1301 to the U.S. Army's research programme on malaria.

\section{References}

Ansdell, V. E., et al. (1974). British Medical fournal, 2, 206.

Bartelloni P. J. Sheehy T. W., and Tigertt, W. D. (1967). Fournal of the American Medical Association 199, 173.

Brodie, B. B. Udenfriend S. and Baer J. (1947). Fournal of Biological Chemistry 168, 299.

Brooks, M. H 168, 299. Clinical Pharmacology and Therapeutics, 10, 85. Chin, W., et al. (1966). American fournal of Tropical Medicine and Hygiene 15,823 .

Doberstyn, E. B., et al. (1975). Submitted for publication.

Earle, W. C., and Perez, M. (1932). Fourna! of Laboratory and Clinical Medicine, 17, 1124.

Ebisawa, I., et al.'(1970). Fapanese fournal of Experimental Medicine, 40, 151 Glazko, A. J., et al. (1968). American fournal of Tropical Medicine and Hygiene, 17, 465.

Hall, A. P., et al. (1973). Clinical Pharmacology and Therapeutics, 14, 580

Hall, A. P. (1974). Southeast Asian fournal of Tropical Medicine and Public Health, 5, 413.

Hall, A. P., et al. (1975 a). Transactions of the Royal Society of Tropical Medicine and Hygiene. In press.

Hall, A. P., et al. (1975 b). British Medical fournal, 2, 12.

Harrison, T. R. (1974). Principles of Internal Medicine, 7th ed., p. 1019. New York, McGraw Hill.

Lancet, 1971, 2, 855.

Laing, A. B. G. (1964). British Medical fournal, 2, 1439.

Laing, A. B. G. (1964). British Medical fournal, 2, 1439.

Richards, W. H. G. (1970). Advances in Pharmacology and Chemotherapy, 8,121 .

Schwartz, D. E., and Rieder, J. (1970). Chemotherapy, 15, 337.

Segal, H. E., et al. (1975). Transactions of the Royal Society of Tropical Medicine and Hygiene. In press.

Seneca, H. (1966). Fournal of the American Medical Association, 198, 975.

Smith, C. C., and Ihrig, J. (1959). American fournal of Tropical Medicine and Hygiene, 8, 60.

Sonntag, A. C., Stenger, V. G., and Maren, T. H. (1972). Fournal of Pharmacology and Experimental Therapeutics, 182, 48.

World Health Organization (1967). Technical Report Series, No. 375. Geneva W.H.O.

World Health Organization (1973). Technical Report Series, No. 529, p. 8. Geneva, W.H.O.

\title{
Origin of Urinary Fibrin/Fibrinogen Degradation Products in Glomerulonephritis
}

\author{
M. EKBERG, M. PANDOLFI
}

British Medical fournal, 1975, 2, 17-19

\section{Summary}

To elucidate the origin of the fibrin/fibrinogen degradation products (F.D.P.) occurring in the urine in glomerulonephritis 28 patients with glomerulonephritis were examined for renal fibrinolytic activity, F.D.P. in urine and serum, and blood fibrinolytic activators and inhibitors. Unlike the glomeruli of healthy

General Hospital, (University of Lund), Malmo, Sweden M. EKBERG, M.D., Senior Nephrologist, Renal Unit, Department of cine I

M. PANDOLFI, M.D., Associate Professor, Coagulation Laboratory kidneys, which were fibrinolyticly inactive, those of kidneys with glomerulonephritis constantly showed fibrinolytic activity. The presence or absence of fibrin in the glomeruli was almost always accompanied by, respectively, the presence or absence of urinary F.D.P., which suggested a renal origin of urinary F.D.P. in glomerulonephritis. The low fibrinolytic activity of the blood and the absence of F.D.P. in the serum of these patients make it unlikely that the urinary F.D.P. in glomerulonephritis result from glomerular filtration.

\section{Introduction}

In glomerulonephritis basement membrane antibodies or circulating antigen-antibody complexes are believed to activate 